\title{
Long-term evolution of understorey plant species composition after logging in chestnut coppice stands (Cevennes Mountains, southern France)
}

\author{
Hélène GONDARD*, François ROMANE \\ CEFE-CNRS, 1919 route de Mende, 34293 Montpellier Cedex 5, France
}

(Received 10 May 2004; accepted 7 July 2004)

\begin{abstract}
In the Cevennes, many abandoned chestnut groves have been turned into coppice stands. It was previously shown that plant diversity decreases after abandonment. Nevertheless, we propose that logging could be an effective means to maintain plant diversity. The main objective of the present study was to analyze plant diversity changes after clear-cutting and thinning of a chestnut coppice stand as compared to a nearby uncut stand. We hypothesized that rapid chestnut growth, and consequently reestablishment of a closed canopy, would lead to a decrease in species richness. In fact, herbaceous plant species richness showed a large but only temporary increase after logging. A surprising result was the high percentage of hemicryptophytes observed after logging. Generally, therophytes are the first invaders of open areas. Hemicryptophytes occurring after logging were common species and no rare species was found, there or in the uncut area. Moreover, the increase of species richness concerned especially anemochorous plants. It appeared that one possibility to preserve plant diversity, at the landscape scale, could be to maintain a mosaic of chestnut groves, abandoned chestnut groves and coppice stands.
\end{abstract}

plant diversity / life form / dispersal mode / leaf area index / management

Résumé - Évolution sur le long terme de la composition végétale de la strate herbacée après coupe forestière de taillis de châtaignier dans les Cévennes dans le sud de la France. Dans les Cévennes, de nombreux vergers de châtaigniers abandonnés sont transformés en taillis. Il a été clairement montré que la diversité végétale diminue après abandon. Toutefois, la coupe forestière pourrait être une solution pour maintenir un certain niveau de diversité. L'objectif de l'étude était d'analyser les changements de la diversité végétale après coupe rase et éclaircie d'un taillis de châtaignier et de comparer avec un taillis voisin non coupé. La richesse spécifique montre une forte augmentation après coupe forestière mais seulement temporaire. Un résultat inattendu a été le pourcentage élevé d'hémicryptophytes observé après coupe rase et éclaircie. Généralement, les thérophytes sont les premiers colonisateurs de milieux ouverts. Les hémicryptophytes installées après coupe sont des espèces communes, aucune espèce remarquable n'a été rencontrée tout comme dans le peuplement non coupé. De plus, l'augmentation de la richesse spécifique concerne essentiellement des espèces anémochores. Il semble qu'une possibilité pour préserver la diversité des plantes, à l'échelle du paysage, serait le maintien d'une mosaïque de vergers de châtaignier entretenus, de vergers de châtaigniers abandonnés et de taillis.

diversité végétale / type biologique / mode dissémination / surface foliaire / gestion

\section{INTRODUCTION}

Logging modifies canopy structure and induces large understorey changes with regards to light [14], temperature and humidity $[1,3,4]$, and chemical and microbiological soil properties [26, 29, 41]. Logging also changes ground surface conditions [7, 19, 22, 33]. All these changes influence spatial distribution of plant species in the understorey, and thus its biodiversity [9]. The general model formulated by Franklin [17] is observed in different forests: plant species diversity increases to a peak some time after logging but well prior to closure of tree canopy, and then declines to its lowest values under canopy closure. It tends, however, to increase again as canopies of young and mature stands reopen. Consequently, and perhaps ironically, periodic logging could be an effective means to increase levels of plant species diversity [42].

In the Cevennes Mountains, in southern France, a large percentage of the often centuries-old chestnut (Castanea sativa Miller) groves have been transformed into coppice stands that are now managed for timber production [40]. These abandoned groves have been progressively colonized by shrubs, shoots sprouted from the base of the old chestnut trees, and the main stems died, or were removed by the forest owners as a source of tannins. The remaining shoots constitute a "natural" coppice

\footnotetext{
* Corresponding author: gondard@ cefe.cnrs-mop.fr
} 


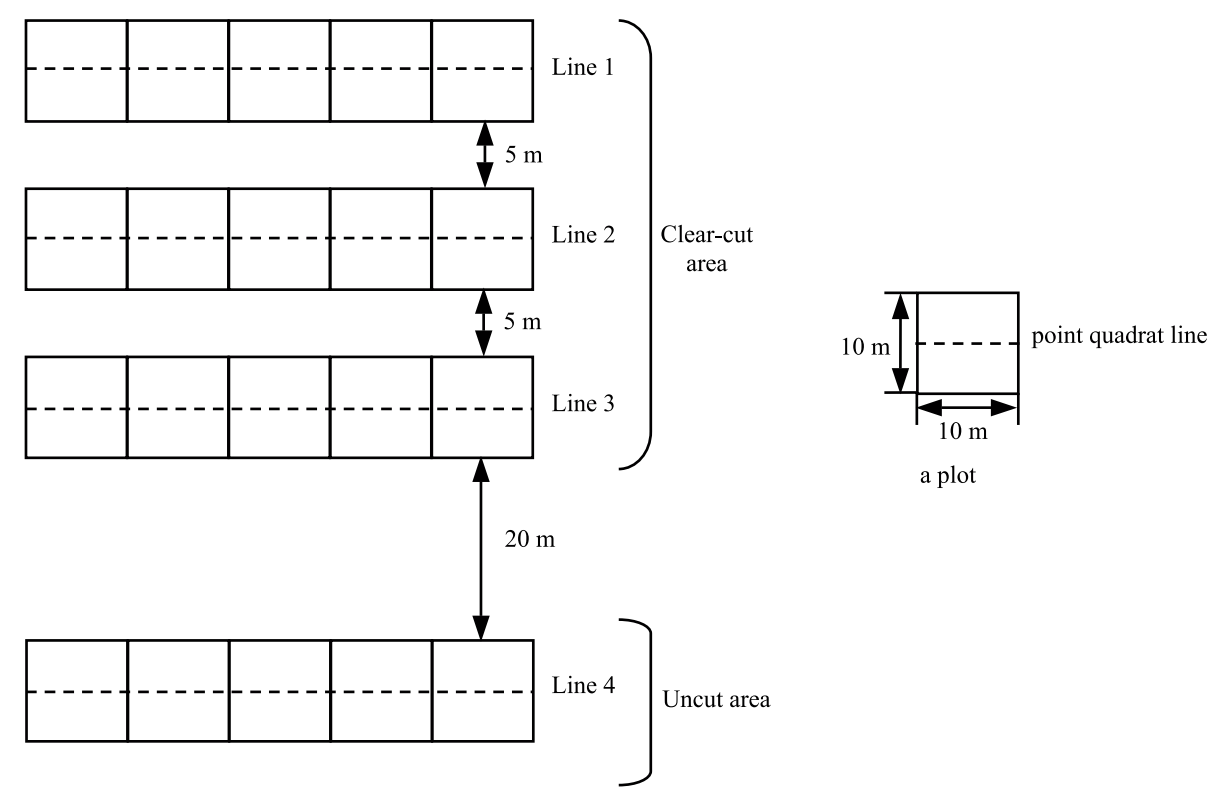

Figure 1. Experimental design at Le Vernet site in the Cevennes Mountains (southern France).

stand or woodland. Gondard et al. [21] reported a strong decrease of plant species diversity after chestnut groves abandonment. Thus, designing new management practices of these chestnut ecosystems could allow foresters to maintain levels of plant species diversity close to that of cultivated groves. To test this hypothesis, our objective was to analyze the evolution of plant species diversity after clear-cutting and thinning of a chestnut coppice stand as compared to a nearby uncut stand by using several diversity index. If it is well-known that plant species richness initially increases after clear-cutting in such ecosystems [41], we sought to elucidate the long-term response of plant species diversity of an ageing chestnut coppice. Moreover, we tried to determine if a correlation exists between canopy closure and species richness. Indeed, opening the canopy increases light availability and this is a very important factor influencing biodiversity dynamics [4, 18, 24, 51]. The analyses of plant species diversity variations after logging were also approached by plant functional traits and not only by species in order to obtain an indication about ecosystem functioning [35]. We focused on life forms [38] which are a synthesis of several life traits. They integrate both morphological and physiological criteria [15]. We also analyzed dispersal modes, which are often related to response to disturbances [25, 31, 50] due to their essential role in dynamics and structure of plant species populations [47]. We hypothesized that annuals and wind-dispersed species would characterize the first year after logging, and that long-lived trees and animal-dispersed species would characterize the uncut stand.

\section{MATERIALS AND METHODS}

\subsection{Study site}

The study was carried out in Le Vernet $\left(44^{\circ} 08^{\prime} \mathrm{N} ; 03^{\circ} 48^{\prime} \mathrm{E}\right)$ situated at $700 \mathrm{~m}$ a.s.l. in the Cevennes Mountains in Southern France.
The region experiences a Mediterranean climate with dry, warm summers and cool, humid winters [11]. However, it is also marked by the oceanic influences from the Atlantic that frequently alleviate potential drought conditions during the summer. Thus, we consider the climate in the Cevennes as being transitional between Mediterranean and Oceanic. The mean annual rainfall is about $1300 \mathrm{~mm}$, mainly occurring in the months October through March. Holm oak (Quercus ilex) natural woodlands ranges from 200 to $700 \mathrm{~m}$ a.s.l. in drier habitats (southfacing slope, rock areas) with chestnut occurring where the ecological conditions are more favourable, i.e., on north-facing slopes with deep, moisture-retaining soils. The chestnut is apparently replacing the original natural woodlands of downy oak $(Q$. pubescens) throughout the zone, from about 300 to $900 \mathrm{~m}$ a.s.l. Above this altitude, European beech (Fagus sylvatica) dominates, occasionally mixed with fir (Abies alba) [36].

The experimental site is in the Gardon state forest managed by the French Office National des Forêts (ONF) where the chestnut coppice stand, derived from old chestnut groves, was about 22 years old (shoot age), and $16 \mathrm{~m}$ high on average, at the time of clear-cutting during the winter of 1992-1993. Before clear-cutting, the basal area of chestnuts was about $30 \mathrm{~m}^{2} \mathrm{ha}^{-1}$ with 2000 shoot ha-1 (ONF, pers. comm.). We chose this site because it appeared to be representative of a large part of the forest vegetation in the Cevennes Mountains, in the National Park and nearby. The forest managers also repeatedly request information or suggestions concerning biodiversity management in this kind of forest stands.

\subsection{Experimental design and vegetation sampling}

Due to the fact that our team was not able to independently finance an experimental set-up, we used an existing experiment of the Office National des Forêts designed for other objectives. That explains some of the unsatisfactory aspects of the design such as the unbalanced number of plots between the cut and the uncut areas, the absence of observations the year after clear-cutting and the absence of repetitions. Data processing methods adopted took these shortcomings into account. We used non-parametric test that allows to work with low size samples.

Our experiment consisted of 20 square plots $(10 \times 10 \mathrm{~m}$ each $), 15$ of which were in the clear-cut area and 5 in the uncut area (control) (Fig. 1). Visual observations showed that vegetation in the uncut area 


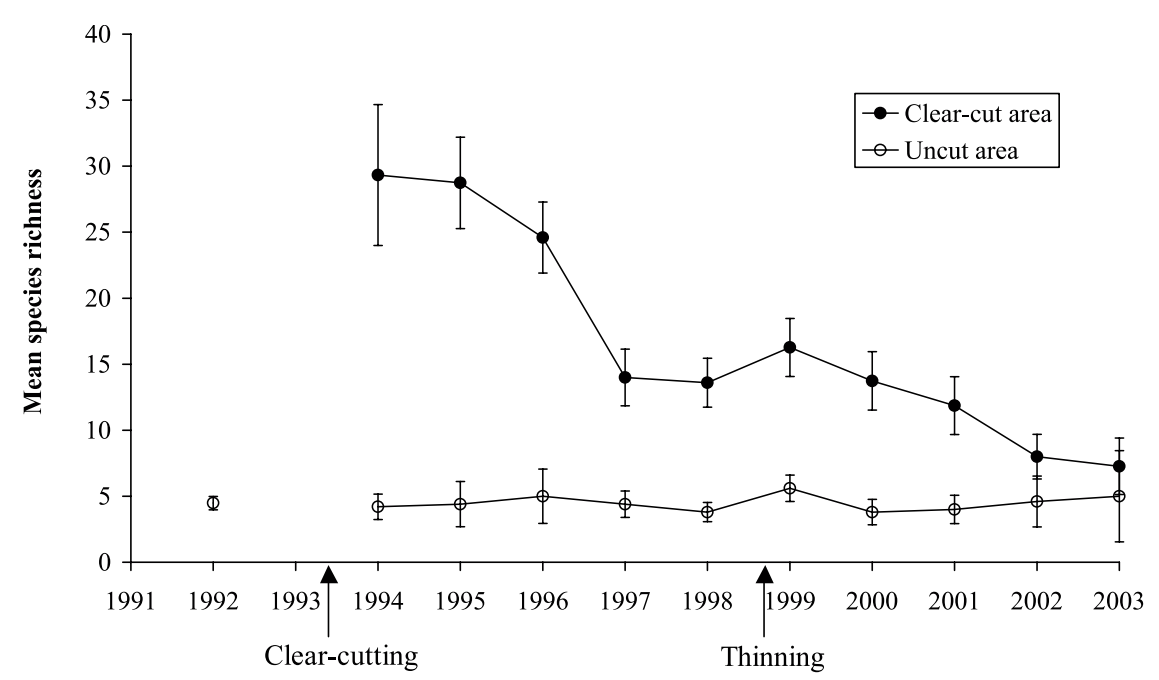

Figure 2. Evolution of mean species richness after logging of a chestnut coppice stand of 22 years old at Le Vernet site in the Cevennes Mountains (southern France). Error bars set at $\pm 95 \%$ confidence limits.

was highly homogeneous, thus 5 plots were considered a sufficient number to sample this 'control' situation. The 20 cut-plots were situated along 4 parallel lines perpendicular to the slope. The 5 plots by line were contiguous because there was only very little area available at the site with relatively homogeneous topographic conditions, and in order to respect a $100 \mathrm{~m}^{2}$ plot size minimum. Moreover, due to topography, the distance was about $5 \mathrm{~m}$ between line 1 , line 2 and line 3 and $20 \mathrm{~m}$ between line 3 and line 4 (control).

In each plot, all plant species (except mosses and lichens) present in the understorey $(0-50 \mathrm{~cm}$ above soil) were listed to obtain species richness (total number of vascular species) (Appendix). Each species recorded was characterized by its life form at the adult stage, according to Raunkiaer's system [38], and using local plant guides; phanerophyte (tree), chamaephyte (shrub), geophyte (bulbous plant), hemicryptophyte (herbaceous perennial), and therophyte (annual). Moreover, the dispersal mode of each plant species was assigned from Molinier and Müller [32] and field observations; anemochorous (seeds dispersed by wind), zoochorous (seeds dispersed by animal), barochorous (seeds dispersed by gravity), hydrochorous (seeds dispersed by water), and autochorous (seeds dispersed by plant itself). Total plant cover was estimated by the point quadrat method [23]. We used 100 points along a $10 \mathrm{~m}$ line (one point every $10 \mathrm{~cm}$ ) running through the middle of each plot and perpendicular to the slope. Unfortunately, no measurements had been carried out before the clear-cut took place. However, the 'control' plot that had not been cut provided a rather good estimation of the flora and vegetation present in the site as a whole before the clear-cut.

The 15 plots were clear-cut in winter 1992/1993, but we could not monitor the vegetation in 1993 because we did not know that clearcut was realized. In 1998, plant species richness had declined and appeared to have stabilized. Thus, foresters practiced a chestnut thinning to complete the role of the clearing. This thinning was realized in the winter 1998/1999 by removing, in the 15 plots that have been clear-cut 6 years ago, about one third of the tree shoots existing at that time, ca. 9200 shoots ha ${ }^{-1}$. Thus, for species richness and diversity assessments, the plots were monitored each year from 1994 until 2003. The observations were carried out in May, June and July, to record all, or almost all, the species present. For species abundance, point quadrats were carried out in May or June each year in all 20 plots when the vegetation had reached its 'maximum' or peak of growth. To estimate the diversity of the plots before clear-cut, we used the mean diversity of the ten available years (1994-2003) of the 5 uncut plots.
The Leaf Area Index (LAI) of the overstorey canopy was measured with a Licor ${ }^{\circledR} 2000$ device $[28,48]$ at the centre of each $10 \times 10 \mathrm{~m}$ plot. The measurements were performed in July of each year, at sunrise, to have a uniform luminosity.

\subsection{Statistical analyses}

To compare plots, we used species richness (species number), which is the most simple diversity index, Shannon index, which is easy to measure and the most used [34], and evenness, which give information on the presence of dominant species (evenness tends towards 1 when all species have the same abundance value, and towards 0 when a single species is dominant) [6]. Mean ranks pairwise comparisons were realized by the Mann-Whitney non-parametric test in order to avoid normality and homoscedasticity verification [13]. The percentage comparisons of life form spectrum and dispersal mode spectrum were performed by $\chi^{2}$ test [13]. To determine whether a correlation existed between LAI and species richness, the non-parametric correlation coefficient of Spearman was preferred to other coefficients due to the sample size which was not large [13].

\section{RESULTS}

\subsection{Species richness, species diversity and evenness}

The clear-cut of the 22 years old chestnut coppice carried out during the winter of 1992/1993 induced a drastic increase of plant species richness with 25 new plant species appearing. Species richness estimated at $4.5 \pm 0.5$ before clear-cut, reached $29.7 \pm 5.2$ two years after clear-cut (Fig. 2 and Tab. I). However, from 1994 until 1997, plant species richness decreased quickly, with the loss of 15 plant species. Between 1997/1998, species richness was rather stable, but always significantly higher than in the uncut area. Only one year after thinning, in 1999, species richness increased significantly. But this increase was short in time since species richness decreased until 2003 (loss of 9 plant species). However, ten years after logging, species richness was always significantly higher than before the logging. 


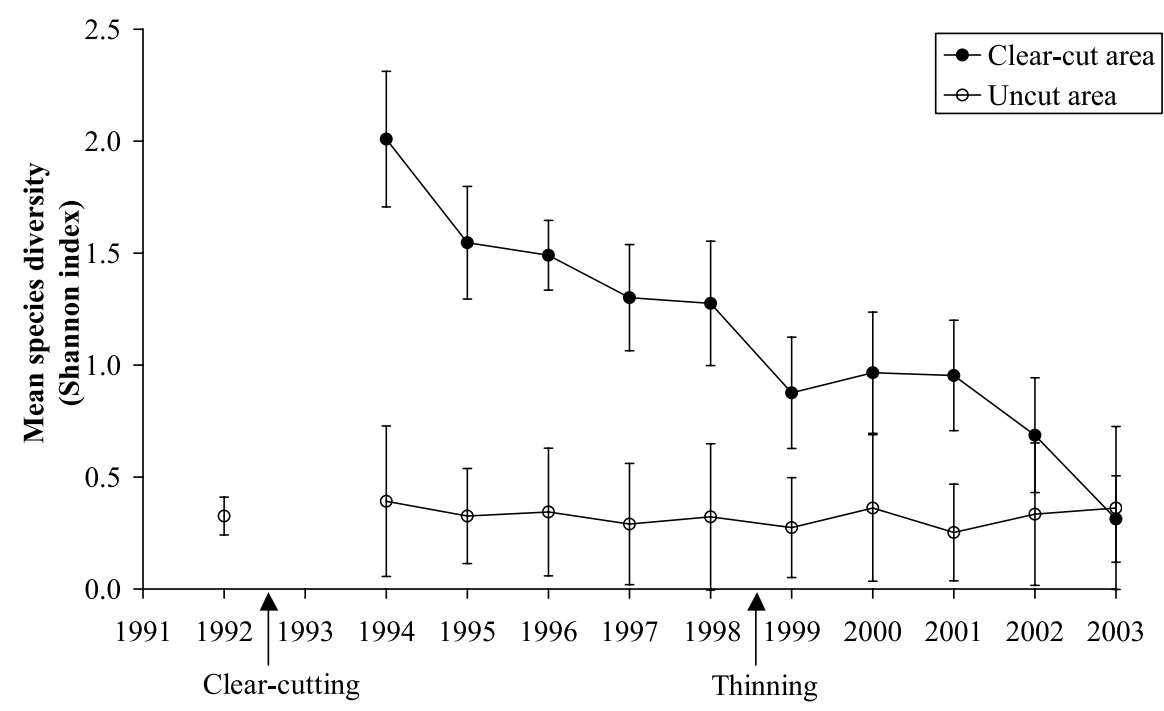

Figure 3. Evolution of mean species diversity after logging of a chestnut coppice stand of 22 years old at Le Vernet site in the Cevennes Mountains (southern France). Error bars set at $\pm 95 \%$ confidence limits.

Tableau I. Mann-Whitney non parametric test results for mean rank comparison of species richness, species diversity and evenness in uncut area and clear-cut area between years. Two different letters indicate significantly different mean rank values, $p<0.05$.

\begin{tabular}{|c|c|c|c|c|c|c|c|c|c|c|c|c|}
\hline & & 1992 & 1994 & 1995 & 1996 & 1997 & 1998 & 1999 & 2000 & 2001 & 2002 & 2003 \\
\hline \multirow[t]{2}{*}{ Species richness } & Uncut area & $\mathrm{a}$ & $\mathrm{a}$ & a & $\mathrm{a}$ & $\mathrm{a}$ & $\mathrm{a}$ & a & $\mathrm{a}$ & a & a & $\mathrm{a}$ \\
\hline & Clear-cut area & - & $\mathrm{b}$ & $\mathrm{b}$ & $\mathrm{b}$ & $\mathrm{cd}$ & $\mathrm{cd}$ & $\mathrm{c}$ & $\mathrm{cd}$ & d & $\mathrm{e}$ & $\mathrm{e}$ \\
\hline \multirow{2}{*}{$\begin{array}{l}\text { Species diversity } \\
\text { (Shannon index) }\end{array}$} & Uncut area & a & $\mathrm{a}$ & a & a & a & a & a & a & a & a & a \\
\hline & Clear-cut area & - & $\mathrm{b}$ & $\mathrm{bc}$ & $\mathrm{c}$ & $\mathrm{cd}$ & $\mathrm{cd}$ & de & de & de & $\mathrm{e}$ & $\mathrm{a}$ \\
\hline \multirow[t]{2}{*}{ Evenness } & Uncut area & $a b$ & $a b$ & $a b$ & $a b$ & $a b$ & $a b$ & $a b$ & $a b$ & $a b$ & $a b$ & $a b$ \\
\hline & Clear-cut area & - & $\mathrm{c}$ & $\mathrm{cd}$ & $\mathrm{d}$ & cde & $\mathrm{cd}$ & $\mathrm{e}$ & a & $\mathrm{a}$ & a & $\mathrm{b}$ \\
\hline
\end{tabular}

Trends in biodiversity changes after logging, according to species diversity and evenness, were very similar to those of the species richness except after thinning. Indeed, Shannon index (Fig. 3 and Tab. I) and evenness (Fig. 4 and Tab. I) increased quickly two years after clear-cut, decreased slowly during the following five years, but no significantly trend was observed after thinning. Diversity decreased from 1994 to obtain in 2003 the same diversity than in the uncut area, and evenness has been the same as in the uncut area since 2000, showing the increasing dominance of the chestnut.

\subsection{Species richness in term of life form and dispersal mode}

Life form spectrum (Fig. 5) showed large variation of hemicryptophytes and phanerophytes following logging. Geophytes stayed very stable in species number. Therophytes and chamaephytes had very low species richness; consequently the data did not allow statistical comparisons. Two years after clear-cut, hemicryptophytes increased significantly $\left(\chi_{(1)}^{2}=3.9 ; p<0.05\right)$, while phanerophytes decreased significantly $\left(\chi^{2}{ }_{(1)}=10.6\right.$; $p<0.001)$. Between 1994 and 1998, it was the inverse, hemicryptophytes decreased $\left(\chi_{(1)}^{2}=24.0 ; p<0.001\right)$, while phanerophytes increased $\left(\chi^{2}(1)=18.23 ; p<0.001\right)$. After thinning (between 1998-1999), hemicryptophytes increased again $\left(\chi_{(1)}^{2}=6.2 ; p<0.05\right)$, while phanerophytes decreased $\left(\chi_{(1)}^{2}=4.05\right.$; $p<0.05)$. From 1999, hemicryptophytes decreased $\left(\chi_{(1)}^{2}=\right.$ $8.3 ; p<0.01)$, and phanerophytes increased $\left(\chi^{2}(1)=5.7\right.$; $p<0.05$ ).

Species richness in term of dispersal modes was very low in the uncut area, thus it was impossible to use them for statistical analyses. Considering only the clear-cut area, dispersal mode spectrum (Fig. 6) showed the dominance of anemochorous. From 1994 to 2003, anemochorous decreased significantly $\left(\chi^{2}(1)=4.8 ; p<0.05\right)$, and barochorous increased significantly $\left(\chi^{2}(1)=10.42 ; p<0.001\right)$ to reach percentage values similar to the values observed before clear-cut in 1992. The other dispersal mode were very stable from 1994 to 2003; zoochorous $\left(\chi_{(1)}^{2}=0.7 ; p>0.05\right)$, autochorous $\left(\chi_{(1)}^{2}=0.3 ; p>0.05\right)$, hydrochorous $\left(\chi_{(1)}^{2}=2.25 ; p>0.05\right)$. 


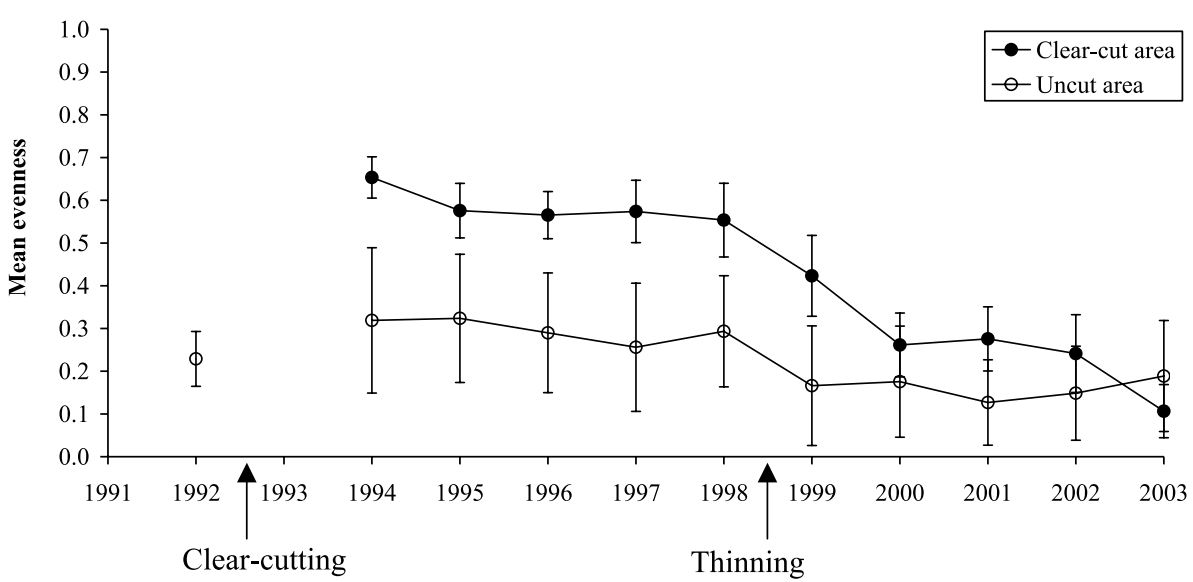

Figure 4. Evolution of mean evenness after logging of a chestnut coppice stand of 22 years old at Le Vernet site in the Cevennes Mountains (southern France). Error bars set at $\pm 95 \%$ confidence limits.

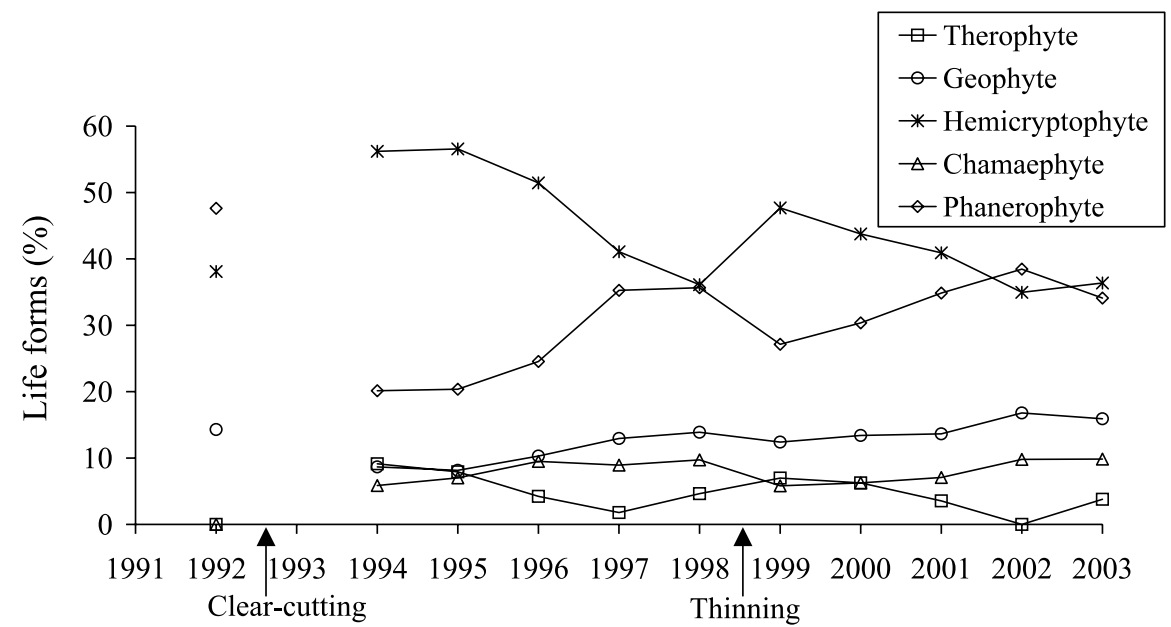

Figure 5. Evolution of life form spectrum changes after logging of a chestnut coppice stand of 22 years old at Le Vernet site in the Cevennes Mountains (southern France).

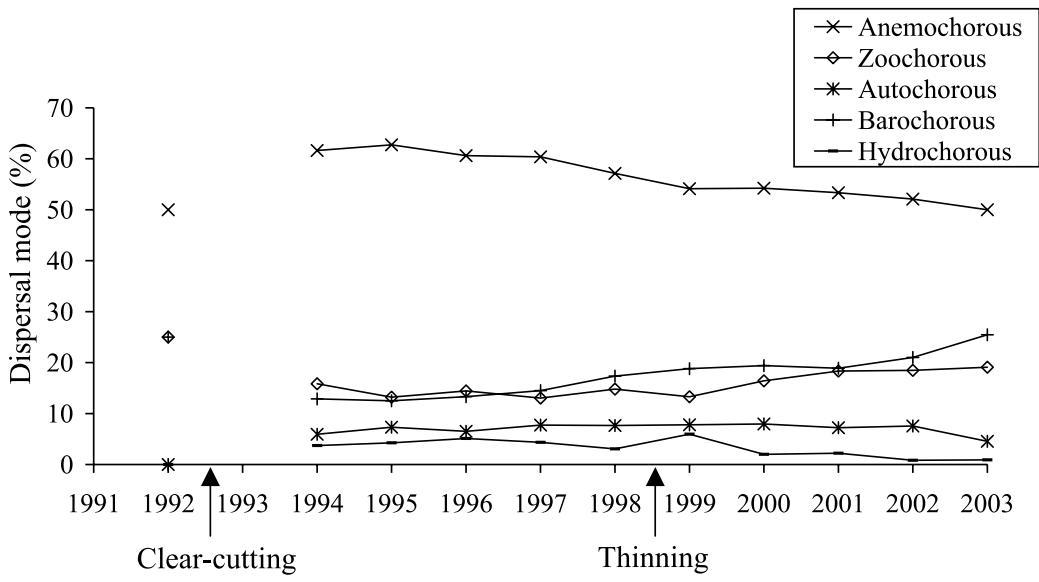

Figure 6. Evolution of dispersal mode spectrum changes after logging of a chestnut coppice stand of 22 years old at Le Vernet site in the Cevennes Mountains (southern France). 


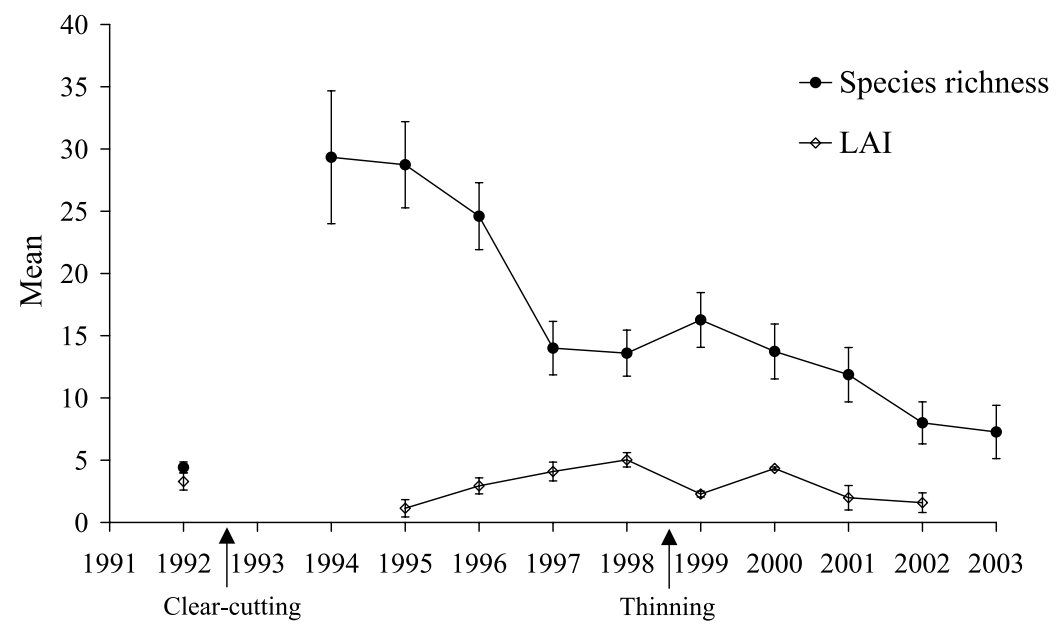

Figure 7. Evolution of species richness and Leaf Area Index (LAI) after logging of a chestnut coppice stand of 22 years old at Le Vernet site in the Cevennes Mountains (southern France). Error bars set at $\pm 95 \%$ confidence limits.

\subsection{Species richness and Leaf Area Index (LAI)}

The data shown in Figure 7 suggested that species richness was related to LAI (i.e. increasing species richness with decreasing LAI values). Nevertheless the Spearman rank correlation coefficient did not allow to confirm this trend.

\section{DISCUSSION AND CONCLUDING REMARKS}

In our study, the temporary large increase of plant species richness observed especially after clear-cutting, but also after thinning, of chestnut coppice stand was not surprising. Indeed, the increase of plant species richness after logging was observed by many authors $[2,10,20,30,44]$, as well as after other disturbances like fire and cultural abandonment. [12, 37, 39, 45]. Nevertheless, the intensity of this process in the present study was remarkably high, since the initial plant species richness was only about 5 species per $100 \mathrm{~m}^{2}$ plot in the original old coppice stand and it reached about 30 species per plot 2 years after the clear-cutting declined to 14 species 3 years later.

It appears that light could be an important factor to the maintenance of high understorey species diversity, even if the relationship between LAI and species richness was not statistically significant. This overall result was probably induced by the high variability of LAI values, but suggested the possible impact of the logging on other ecosystem processes such as water cycle, nutrient fluxes, etc. The decrease of diversity only few years after logging could be related to the good aptitude of chestnut stand to re-build quickly a homogeneous canopy cover after logging [5]. However, other factors like rainfall pattern in the understorey, chemical soil properties, etc. could probably help to better understand our results.

A surprising result in our study was the high percentage of hemicryptophytes observed after clear-cutting and thinning. Generally, therophytes (annuals) are the main life form appearing in the early stages of a succession $[12,27]$. The low number of therophyte species could be explained by the environment around the site which is composed essentially of forests. Another hypothesis could be the strong presence of hemicryptophytes seed bank in the soil. The hemicryptophytes appearing after clear-cutting or thinning were common species (Poa nemoralis, Anthoxanthum odoratum, etc.) as well as in the uncut area (Festuca rubra, Hieracium murorum, etc.). Moreover, the increase of species richness concerns especially anemochorous plant species. Indeed, we found that plant species with wind dispersed seeds were dominant in chestnut coppice stands whatever year considered (before or after logging). Thus, it was not totally conform to our start hypothesis.

In management strategies, if species richness and plant diversity are sought to be favored, our results indicated that a landscape with mainly chestnut coppice stands would be a very poor management option. The recently clear-cut areas, where diversity could be higher, would become progressively more impoverished under such a regime. One possibility to preserve plant diversity could be to maintain a mosaic, at the landscape scale [16], of chestnut groves, abandoned chestnut groves and coppice stands [21,41]. This could possibly help managers and foresters to achieve a management and sustainable development program compatible with plant diversity conservation [8, 43, 49]. However, due to some of the unsatisfactory aspects of the experimental design (only one site, in a single context), our study only indicates, but does not validate, several possible management techniques, of which remain to be tested further.

Acknowledgements: We thank the European Union (MANCHEST contracts, DG XII), the French Ministère de l'Environnement and the Parc National des Cévennes for their help in this project. We also warmly thank Michel Grandjanny, Anna Grossmann, Marie Maistre, Alain Renaux and Zuheir Shater for their help in collecting data. We are grateful to James Aronson for text revision.

\section{REFERENCES}

[1] Anderson R.C., Loucks O.L., Swain A.M., Herbaceous response to canopy cover, light intensity, and throughfall precipitation in coniferous forests, Ecology 50 (1969) 255-263. 
[2] Bartolome J.W., Allen-Diaz B.H., Tietje W.D. The effect of Quercus douglasii removal on understorey yield and composition, J. Range Manage. 47 (1994) 151-154.

[3] Chen J., Franklin J.F., Spies T.A., Contrasting microclimates among clearcut, edge, and interior of old-growth Douglas-fir forest, Agric. For. Meteor. 63 (1993) 219-237.

[4] Collins B.S., Pickett S.T.A., Influence of canopy opening on the environment and herb layer in southern hardwood forest, Vegetatio 70 (1987) 3-10.

[5] Cutini A., New management options in chestnut coppices: an evaluation on ecological bases, For. Ecol. Manage. 141 (2001) 165174.

[6] Daget J., Modèles mathématiques en écologie, Masson, Paris, 1976.

[7] Deconchat M., Effets des techniques d'exploitation forestière sur l'état de surface du sol, Ann. For. Sci. (2001) 653-661.

[8] Di Castri F., The ecosystem in a scientific, economic and social context. Is sustainability possible? in: Leonardi S. (Ed.), Sustainability of chestnut forest ecosystems, Abstract proceedings of an International Symposium, Catania, Italy, 1998, pp. 22-24.

[9] Ehrenfeld J.G., Understorey response to canopy gaps of varying size in a mature oak forest, Bull. Torrey Bot. Club 107 (1980) 2941.

[10] Elliot K.J., Swank W., Change in tree species diversity after successive clearcuts in the Southern Appalachian, Vegetatio 155 (1994) $11-18$.

[11] Emberger L., Une classification biogéographique des climats, Rec. Trav., Lab. Bot. Géol. Zool., Université de Montpellier, série Bot. 7 (1995) 3-43.

[12] Escarré J., Houssard C., Debussche M., Lepart J., Évolution de la végétation méditerranéenne : étude de succession dans les garrigues du Montpelliérais (France), Acta Oecol., Oecol. Plant. 4 (1983) 221-239.

[13] Falissard B., Comprendre et utiliser les statistiques dans les sciences de la vie, Coll. Évaluation et Statistique, Masson, Paris, 1998.

[14] Federer C.A., Tanner C.B., Spectral distribution of light in the forest, Ecology 47 (1966) 555-560.

[15] Floret C., Galan M.J., Le Floc'h E., Orshan G., Romane F., Growth forms and phenomorphology traits along an environmental gradient: tools for studying vegetation? J. Veg. Sci. 1 (1990) 71-80.

[16] Forman R.T.T., Godron M., Landscape ecology, Wiley, New-York, 1986.

[17] Franklin J.F., Old-growth forests in the Pacific North-west: an ecological view, in: Old-growth forests: a balanced perspectives, University of Oregon, Bur. Gov. Res. Serv., Eugene, Oregon, USA, 1982, pp. 5-27.

[18] Gilliam F.S., Turrill N.L., Bethadams M., Herbaceous-layer and overstory species in clear-cut and mature central Appalachian hardwood forests, Ecol. Appl. 5 (1995) 947-955.

[19] Gondard H., Deconchat M., Effects of soil surface disturbances after logging on plant functional types, Ann. For. Sci. 60 (2003) 725-732.

[20] Gondard H., Aronson J., Grandjanny M., Le Floc'h E., Renaux A., Romane F., Shater Z., Plant species richness responses to management practices in chestnut (Castanea sativa Miller) forests and coppice stands in the Cévennes mountains (southern France), Ecol. Mediterr. 26 (2000) 143-154.

[21] Gondard H., Romane F., Grandjanny M., Junqing L., Aronson J., Plant species diversity changes in abandoned chestnut (Castanea sativa) groves in southern France, Biodiv. Conserv. 10 (2001) 189207.

[22] Gondard H., Jauffret S., Aronson J., Lavorel S., Plant functional types: a promising tool for management and restoration of degraded lands, Appl. Veg. Sci. 6 (2003) 223-234.

[23] Goodall D.W., Point quadrat methods for the analysis of vegetation. The treatment of data for tussock grasses, Aust. J. Bot. 1 (1953) 457-461.

[24] Grime J.P., Jarvis B.C., Shade avoidance and shade tolerance in flowering plants. II. Effects of light on the germination of species of contrasted ecology, in: Evans G.C., Bainbridge R., Rackham O. (Eds.), Light as an Ecological Factor II, Blackwell Scientific Publications, Oxford, 1975, pp. 525-532.
[25] Guitián J., Sánchez J.M., Seed dispersal spectra of plant communities in the Iberian Peninsula, Vegetatio 98 (1992) 157-164.

[26] Kropp B.R., Albee S., The effects of sylvicultural treatments on occurrence of mycorrhizal sporocarps in a Pinus contorta forest: a preliminary study, Biol. Conserv. 78 (1996) 313-318.

[27] Lavorel S., McIntyre S., Grigulis K., Plant response to disturbance in a Mediterranean grassland: How many functional groups? J. Veg. Sci. 10 (1999) 661-672.

[28] Li-cor ${ }^{\circledR}$, LAI-2 000 Plant Canopy Analyser, Instrument Manual, Box 4 425/4 421 Superior St. Lincoln, Nebraska, USA, 1992.

[29] Likens G.E., Bormann F.H., Pierce R.S., Reiners W.A., Recovery of deforested ecosystem. Replacing the biomass nutrients lost in harvesting northern hardwood may take 60 to 80 years, Science 199 (1978) 492-496.

[30] Mason C.F., MacDonald S.M., Responses of ground flora to coppice management in an English woodland - a study using permanent quadrats, Biodiv. Conserv. 11 (2002) 1773-1789.

[31] Metzger J.P., Tree functional group richness and landscape structure in a Brazilian tropical fragmented landscape, Ecol. Appl. 10 (2000) 1147-1161.

[32] Molinier R., Müller P., La dissémination des espèces végétales, Lesot A (Ed.), Paris, Vol. 64, 1938.

[33] Pennock D.J., Vankessel C., Clear-cut forest harvest impacts on soil quality indicators in the mixedwood forest of Saskatchewan, Canada, Geoderma 75 (1997) 13-32.

[34] Pielou R.H., Ecological diversity, Wiley Intersciences, 1975.

[35] Pillar V.D., On the identification of optimal plant functional types, J. Veg. Sci. 10 (1999) 631-640.

[36] Pitte M.W., Terres de castanides, hommes et paysages du châtaignier de l'antiquité à nos jours, Editions Fayard, Evreux, 1986.

[37] Prach K., Pysek P., Smilauer P., Changes in species traits during succession: a search for pattern, Oikos 79 (1997) 201-205.

[38] Raunkiaer C., The life-forms of plants and statistical plant geography, Oxford University Press, Oxford, 1934.

[39] Romane F., Trabaud L., Valérino L., Are human impacts decreasing the biodiversity in Mediterranean Basin ecosystems? Noticerio de Biologia (Soc. Biol. Chile) 2 (1994) 49.

[40] Romane F., Valérino L., Changements de biodiversité dans les châtaigneraies cévenoles (sud de la France), Ecol. Mediterr. 23 (1997) $121-129$.

[41] Rubio A., Escudero A., Clear-cut effects on chestnut forest soils under stressful conditions: lengthening of time-rotation, For. Ecol. Manage. 183 (2003) 195-204.

[42] Rubio A., Gavilán R., Escudero A., Are soil characteristics and understorey composition controlled by forest management? For. Ecol. Manage. 113 (1999) 191-200.

[43] Shearman R., The meaning and ethics of sustainability, Environ. Manage. 14 (1990) 1-8.

[44] Tatoni T., Roche P., Comparison of old-field and forest revegetation dynamics in Provence, J. Veg. Sci. 5 (1994) 295-302.

[45] Trabaud L., Lepart J., Diversity and stability in garrigues ecosystems after fire, Vegetatio 43 (1980) 49-57.

[46] Tutin T.G., Heywood V.H., Burges N.A., Moore D.M., Valentine D.H., Walters S.M., Webb D.A., Flora europea, Cambrige University Press, 1964-1980.

[47] Van Der Pijl L., Principles of dispersal in higher plants, Springer, Berlin, Heidelberg and New York, 1982.

[48] Welles J.M., Norman J.M., Instrument for indirect measurement of canopy architecture, Agron. J. 83 (1991) 818-825.

[49] Wikstrom P., Solving the stand management problem under biodiversity-related considerations, For. Ecol. Manage. 126 (1999) 361376.

[50] Willson M.F., Rice B.L., Westoby M., Seed dispersal spectra: a comparison of temperate plant communities, J. Veg. Sci. 1 (1990) 547-562.

[51] Yorks T.E., Dabydeen S., Seasonal and successional understory vascular plant diversity in second growth hardwood clearcuts of western Maryland, USA, For. Ecol. Manage. 119 (1999) 217-230. 


\section{APPENDIX}

Presence (+) or absence (-) of the plant species in the chestnut coppice stand of 22 years old at Le Vernet site in the Cevennes Mountains (Southern France). One species is noted (+) when it is present at least in one plot and is noted (-) when it is absent in all plots. Nomenclature from Tutin et al. (1964-1980) [46].

\begin{tabular}{|c|c|c|c|c|c|c|c|c|c|c|c|c|c|c|c|c|c|c|c|c|c|c|}
\hline \multirow[t]{2}{*}{ Species } & \multirow[t]{2}{*}{$\mathrm{LF}$} & \multirow[t]{2}{*}{ DM } & \multicolumn{10}{|c|}{ Uncut area } & \multicolumn{10}{|c|}{ Cut area } \\
\hline & & & 1994 & 1995 & 1996 & 1997 & 1998 & 1999 & 2000 & 2001 & 2002 & 2003 & 1994 & 1995 & 1996 & 1997 & 19981 & 19992 & 2000 & 2001 & 2002 & 2003 \\
\hline Anarrhinum bellidifolium & $\mathrm{H}$ & An & - & - & - & - & - & - & - & - & - & - & + & + & - & - & - & - & - & - & - & - \\
\hline Anthoxanthum odoratum & $\mathrm{H}$ & An & - & - & - & - & - & - & - & - & - & - & + & + & + & - & - & - & + & + & - & - \\
\hline Arctium lappa & $\mathrm{H}$ & Zo & - & - & - & - & - & - & - & - & - & - & + & - & - & - & - & - & - & - & - & - \\
\hline Arenaria montana & $\mathrm{H}$ & An & - & - & - & - & - & - & - & - & + & + & + & + & + & + & + & + & + & + & - & - \\
\hline Arenaria serpyllifolia & $\mathrm{H}$ & An & - & - & - & - & - & - & - & - & - & - & + & - & - & - & - & - & - & - & - & - \\
\hline Asplenium obovatum sp. & $\mathrm{H}$ & An & - & - & - & - & - & - & - & - & - & - & - & + & - & - & - & + & - & - & - & - \\
\hline Asplenium trichomanes & $\mathrm{H}$ & An & - & - & - & - & - & - & - & - & - & - & - & + & + & - & - & - & - & + & - & - \\
\hline Asplenium viride & $\mathrm{H}$ & An & - & - & - & - & - & - & - & - & - & - & - & + & - & - & - & - & - & - & - & - \\
\hline Betula pendula & $\mathrm{Ph}$ & An & - & - & - & - & - & - & - & - & - & - & + & + & + & + & + & + & + & + & + & + \\
\hline Calluna vulgaris & $\mathrm{Ch}$ & An & + & + & - & - & - & - & - & - & - & - & + & + & + & + & + & + & - & - & - & - \\
\hline Cardamine amara & $\mathrm{H}$ & $\mathrm{Au}$ & - & - & - & - & - & - & - & - & - & - & - & + & - & - & - & - & - & - & - & - \\
\hline Cardamine flexuosa & $\mathrm{H}$ & $\mathrm{Au}$ & - & - & - & - & - & - & - & - & - & - & - & + & - & - & - & - & - & - & - & - \\
\hline Cardamine hirsuta & $\mathrm{H}$ & $\mathrm{Au}$ & - & - & - & - & - & - & - & - & - & - & + & + & + & - & + & + & - & - & - & - \\
\hline Castanea sativa & $\mathrm{Ph}$ & $\mathrm{Ba}$ & + & + & + & + & + & + & + & + & + & + & + & + & + & + & + & + & + & + & + & + \\
\hline Cedrus atlantica & $\mathrm{Ph}$ & An & + & - & + & - & - & - & - & - & - & - & + & + & + & + & + & + & + & + & + & + \\
\hline Cephalanthera rubra & G & An & - & - & - & - & - & - & - & - & - & + & + & - & - & - & - & - & - & - & - & - \\
\hline Cephalantera longifolia & G & An & - & - & - & - & - & - & - & - & - & - & - & + & - & - & - & - & - & - & - & - \\
\hline Cerastium fontanum & $\mathrm{H}$ & An & - & - & - & - & - & - & - & - & - & - & - & + & - & - & - & - & - & - & - & - \\
\hline Cerastium glomeratum & $\mathrm{H}$ & An & - & - & - & - & - & - & - & - & - & - & + & + & - & - & - & - & - & - & - & - \\
\hline Cirsium acaule & $\mathrm{H}$ & An & - & - & - & - & - & - & - & - & - & - & - & + & - & - & - & - & - & - & - & - \\
\hline Cirsium arvense & $\mathrm{H}$ & An & - & - & - & - & - & - & - & - & - & - & + & + & + & - & - & - & - & - & - & - \\
\hline Clematis vitalba & $\mathrm{Ph}$ & An & - & - & - & - & - & - & - & - & - & - & + & + & + & + & + & + & + & + & + & + \\
\hline Clinopodium vulgare & $\mathrm{H}$ & Hy & - & - & + & - & - & - & - & - & - & - & + & + & + & + & + & + & + & + & + & + \\
\hline Conyza sumatrensis & Th & An & - & - & - & - & - & - & - & - & - & - & + & + & - & - & - & + & + & - & - & - \\
\hline Crepis albida & Th & An & - & - & - & - & - & - & - & - & - & - & - & + & - & - & - & - & - & - & - & - \\
\hline Crepis capillaris & Th & An & - & - & - & - & - & - & - & - & - & - & + & - & - & - & - & - & - & - & - & - \\
\hline Crepis vesicaria ssp. & Th & An & - & - & - & - & - & - & - & - & - & - & - & + & - & - & - & - & - & - & - & - \\
\hline Cytisus scoparius & $\mathrm{Ph}$ & $\mathrm{Au}$ & + & + & + & + & + & + & - & - & + & - & + & + & + & + & + & + & + & + & + & + \\
\hline Daucus carota & $\mathrm{H}$ & An & - & - & - & - & - & - & - & - & - & - & + & + & - & - & - & - & - & - & - & - \\
\hline Deschampsia flexuosa & $\mathrm{H}$ & Zo & - & - & - & - & - & + & + & + & + & + & + & + & + & - & - & + & + & + & + & - \\
\hline Digitalis purpurea & $\mathrm{H}$ & Zo & - & - & - & - & - & - & - & - & - & - & + & + & + & + & + & + & + & + & + & + \\
\hline Dryopteris filix-mas & $\mathrm{H}$ & An & - & - & - & - & - & - & - & - & - & - & - & - & + & - & - & - & - & - & - & + \\
\hline Epilobium & $\mathrm{H}$ & An & - & - & - & - & - & - & - & - & - & - & - & + & - & - & - & - & - & - & - & - \\
\hline Epilobium angustifolium & $\mathrm{H}$ & An & - & - & - & - & - & - & - & - & - & - & + & + & + & + & + & + & - & + & - & - \\
\hline Epilobium lanceolatum & $\mathrm{H}$ & An & - & - & - & - & - & + & - & - & - & + & + & + & + & + & + & + & + & + & - & + \\
\hline Epilobium montanum & $\mathrm{H}$ & An & - & - & - & - & - & - & - & + & + & - & + & + & + & + & + & + & + & + & + & + \\
\hline Erica cinerea & $\mathrm{Ch}$ & An & - & - & - & - & - & - & - & - & - & - & - & + & + & + & + & - & - & - & - & - \\
\hline Erica scoparia & $\mathrm{Ch}$ & An & - & - & - & - & - & - & - & - & - & - & + & + & + & - & + & - & - & - & - & - \\
\hline Eupatorium cannabinum & $\mathrm{H}$ & An & - & - & - & - & - & - & - & - & - & - & + & + & + & - & - & - & - & - & - & - \\
\hline
\end{tabular}

LF: life form, Ch: chamaephytes, G: geophytes, H: hemicryptophytes, Ph: phanerophytes, Th: therophytes. DM: dispersal mode, An: anemochorous, $\mathrm{Au}$ : autochorous, Ba: barochorous, Hy: hydrochorous, Zo: zoochorous. 


\begin{tabular}{|c|c|c|c|c|c|c|c|c|c|c|c|c|c|c|c|c|c|c|c|c|c|c|}
\hline \multirow[t]{2}{*}{ Species } & \multirow[t]{2}{*}{ LF } & \multirow[t]{2}{*}{ DM } & \multicolumn{10}{|c|}{ Uncut area } & \multicolumn{10}{|c|}{ Cut area } \\
\hline & & & 1994 & 1995 & 1996 & 1997 & 1998 & 1999 & 2000 & 2001 & 2002 & 2003 & 1994 & 1995 & 1996 & 1997 & 1998 & 1999 & 2000 & 2001 & 2002 & 2200 \\
\hline Festuca ovina & $\mathrm{H}$ & An & + & + & + & + & + & + & + & + & + & + & + & + & + & + & + & + & + & + & + & + \\
\hline Fragaria vesca & $\mathrm{H}$ & Zo & - & - & - & - & - & - & - & - & - & - & + & + & + & + & + & + & + & + & + & - \\
\hline Galeopsis ladanum & Th & Zo & - & - & + & - & - & - & - & - & - & - & + & + & + & + & - & + & - & - & - & - \\
\hline Galium mollugo & $\mathrm{H}$ & $\mathrm{Ba}$ & - & - & - & - & - & - & - & - & - & - & + & + & + & - & + & - & - & - & - & - \\
\hline Geranium lucidum & $\mathrm{H}$ & Zo & - & - & - & - & - & - & - & - & - & - & + & + & - & - & - & - & - & - & - & - \\
\hline Geranium robertianum & $\mathrm{H}$ & $\mathrm{Au}$ & - & - & - & - & - & - & - & - & - & - & + & + & + & + & - & + & + & - & - & - \\
\hline Hedera helix & $\mathrm{Ph}$ & Zo & - & - & + & + & - & - & + & - & - & - & - & + & + & + & + & + & + & + & + & + \\
\hline Hieracium maculatum & $\mathrm{H}$ & An & - & + & - & - & - & - & - & - & - & - & + & + & + & - & - & + & - & + & + & - \\
\hline Hieracium murorum & $\mathrm{H}$ & An & + & - & + & - & + & + & - & - & - & - & + & + & + & + & + & + & + & + & - & + \\
\hline Hieracium umbellatum & $\mathrm{H}$ & An & - & - & - & - & - & - & - & - & - & - & + & + & + & - & + & + & + & + & + & - \\
\hline Holcus mollis & $\mathrm{H}$ & An & - & - & - & - & - & - & - & - & - & - & - & - & - & - & - & - & - & - & - & - \\
\hline Hypericum humifusum & $\mathrm{H}$ & $\mathrm{Ba}$ & - & - & - & - & - & - & - & - & - & - & + & + & + & - & - & - & - & - & - & - \\
\hline Hypericum perforatum & $\mathrm{H}$ & An & - & - & - & - & - & - & - & - & - & - & + & + & + & + & + & + & + & + & - & + \\
\hline Hypochaeris radicata & $\mathrm{H}$ & An & - & - & - & - & - & - & - & - & - & - & + & + & - & - & - & - & - & - & - & - \\
\hline Jasione montana & $\mathrm{H}$ & An & - & - & - & - & - & - & - & - & - & - & + & + & - & - & - & - & - & - & - & - \\
\hline Juncus effusus & $\mathrm{H}$ & Zo & - & - & - & - & - & - & - & - & - & - & - & + & + & - & - & - & - & - & - & - \\
\hline Juniperus communis & $\mathrm{Ph}$ & Zo & + & + & + & + & + & + & + & + & + & + & + & + & + & + & + & + & + & + & + & + \\
\hline Lactuca serriola & $\mathrm{H}$ & An & - & - & - & - & - & - & - & - & - & - & + & + & - & - & - & - & - & - & - & - \\
\hline Lactuca virosa & $\mathrm{H}$ & An & - & - & - & - & - & - & - & - & - & - & + & - & + & - & - & - & - & - & - & - \\
\hline Linaria repens & $\mathrm{H}$ & An & - & - & - & - & - & - & - & - & + & + & + & + & + & + & + & + & + & + & + & + \\
\hline Lotus corniculatus & $\mathrm{H}$ & $\mathrm{Au}$ & - & - & - & - & - & - & - & - & - & - & + & + & - & - & - & - & + & - & - & - \\
\hline Luzula campestris & $\mathrm{H}$ & Zo & - & - & - & - & - & - & - & - & - & - & + & + & + & + & + & - & + & + & - & + \\
\hline Luzula multiflora & $\mathrm{H}$ & Zo & - & - & - & - & - & - & - & - & - & - & + & + & + & - & - & + & + & + & + & + \\
\hline Medicago lupulina & $\mathrm{H}$ & $\mathrm{Ba}$ & - & - & - & - & - & - & - & - & - & - & + & - & - & - & - & - & - & - & - & - \\
\hline Melilotus albus & $\mathrm{H}$ & Zo & - & - & - & - & - & - & - & - & - & - & + & - & - & - & + & - & - & - & - & - \\
\hline Moehringia trinervia & Th & $\mathrm{Ba}$ & - & - & - & - & - & - & - & - & - & - & + & + & + & + & + & + & + & + & - & + \\
\hline Monotropa hypopitys & $\mathrm{H}$ & An & - & - & + & + & - & - & - & - & - & - & - & - & - & - & - & - & - & - & - & - \\
\hline Mycelis muralis & $\mathrm{H}$ & An & - & - & - & - & - & - & - & - & - & - & + & + & + & + & + & + & + & + & + & + \\
\hline Picris hieracioides & $\mathrm{H}$ & An & - & - & - & - & - & - & - & - & - & - & + & + & - & + & - & - & - & - & - & - \\
\hline Picris pauciflora & $\mathrm{H}$ & An & - & - & - & - & - & - & - & - & - & - & - & + & - & - & - & - & - & - & - & - \\
\hline Pinus pinaster & $\mathrm{Ph}$ & An & - & + & - & + & + & + & - & + & + & - & + & + & + & + & + & + & + & + & + & - \\
\hline Pinus sylvestris & $\mathrm{Ph}$ & An & - & - & - & - & - & - & - & - & - & - & - & - & - & - & + & - & - & - & - & + \\
\hline Plantago lanceolata & $\mathrm{H}$ & An & - & - & - & - & - & - & - & - & - & - & + & + & + & - & - & - & - & - & - & - \\
\hline Plantago major & $\mathrm{H}$ & An & - & - & - & - & - & - & - & - & - & - & + & - & - & - & - & - & - & - & - & - \\
\hline Poa nemoralis & $\mathrm{H}$ & An & - & - & - & - & - & - & - & - & - & + & + & + & + & + & + & + & + & + & + & + \\
\hline Polygonum aviculare & Th & Zo & - & - & - & - & - & - & - & - & - & - & + & - & - & - & - & - & - & - & - & - \\
\hline Polygonum persicaria & Th & $\mathrm{Ba}$ & - & - & - & - & - & - & - & - & - & - & + & - & - & - & - & + & - & - & - & - \\
\hline Polypodium vulgare & G & An & - & - & - & - & - & - & - & - & - & - & + & + & + & + & + & + & + & + & + & + \\
\hline Potentilla erecta & $\mathrm{H}$ & An & - & - & - & - & - & - & - & - & - & - & - & + & - & - & - & - & - & - & - & - \\
\hline Potentilla recta & $\mathrm{H}$ & An & - & - & - & - & - & - & - & - & - & - & + & - & - & - & - & - & - & - & - & - \\
\hline Prunella vulgaris & $\mathrm{H}$ & $\mathrm{Ba}$ & - & - & - & - & - & - & - & - & - & - & - & + & + & - & - & + & + & + & - & - \\
\hline Prunus avium & $\mathrm{Ph}$ & Zo & + & - & + & - & - & - & - & + & - & - & + & + & + & + & + & - & + & + & + & + \\
\hline Pteridium aquilinum & G & An & + & + & + & + & + & + & + & + & + & + & + & + & + & + & + & + & + & + & + & + \\
\hline Quercus ilex & $\mathrm{Ph}$ & Zo & - & - & - & - & - & - & - & - & - & - & - & + & - & - & - & - & - & - & - & - \\
\hline Ranunculus acris & $\mathrm{G}$ & An & - & - & - & - & - & - & - & - & - & - & + & + & - & - & - & - & - & - & - & - \\
\hline
\end{tabular}

LF: life form, Ch: chamaephytes, G: geophytes, H: hemicryptophytes, Ph: phanerophytes, Th: therophytes. DM: dispersal mode, An: anemochorous, $\mathrm{Au}$ : autochorous, Ba: barochorous, Hy: hydrochorous, Zo: zoochorous. 


\begin{tabular}{|c|c|c|c|c|c|c|c|c|c|c|c|c|c|c|c|c|c|c|c|c|c|c|}
\hline \multirow[t]{2}{*}{ Species } & \multirow[t]{2}{*}{$\mathrm{LF}$} & \multirow[t]{2}{*}{$\mathrm{DM}$} & \multicolumn{10}{|c|}{ Uncut area } & \multicolumn{10}{|c|}{ Cut area } \\
\hline & & & 1994 & 1995 & 1996 & 1997 & 1998 & 1999 & 2000 & 2001 & 2002 & 2003 & 1994 & 1995 & 1996 & 1997 & 1998 & 1999 & 2000 & 2001 & 12002 & 22003 \\
\hline Ranunculus bulbosus & G & $\mathrm{Ba}$ & - & - & - & - & - & - & - & - & - & - & + & - & + & + & + & - & + & + & - & - \\
\hline Rubus ulmifolius & $\mathrm{Ch}$ & Zo & - & - & - & - & - & - & - & - & - & - & + & + & + & + & + & + & + & + & + & + \\
\hline Rumex acetosella & $\mathrm{H}$ & An & - & - & - & - & - & - & - & - & - & - & + & + & - & - & - & + & - & - & - & - \\
\hline Rumex obtusifolius & $\mathrm{H}$ & An & - & - & - & - & - & - & - & - & - & - & + & + & - & - & - & - & + & - & - & - \\
\hline Salix caprea & $\mathrm{Ph}$ & An & - & - & - & - & - & - & - & - & - & - & + & + & + & + & + & + & - & - & - & - \\
\hline Sanguisorba minor & $\mathrm{H}$ & Hy & - & - & - & - & - & - & - & - & - & - & + & - & - & - & - & - & - & - & - & - \\
\hline Saponaria officinalis & $\mathrm{H}$ & An & - & - & - & - & - & - & - & - & - & - & + & - & - & - & - & - & - & - & - & - \\
\hline Senecio erucifolius & $\mathrm{H}$ & An & - & - & - & - & - & - & - & - & - & - & + & - & - & - & - & + & - & - & - & - \\
\hline Senecio jacobaea & $\mathrm{H}$ & An & - & - & - & - & - & - & - & - & - & - & + & + & - & - & - & + & - & - & - & - \\
\hline Silene vulgaris & $\mathrm{H}$ & An & - & - & - & - & - & - & - & - & - & - & + & + & + & + & - & + & - & - & - & - \\
\hline Solidago virgaurea & $\mathrm{H}$ & An & - & - & - & - & - & - & - & - & - & + & + & + & + & + & + & - & + & - & - & - \\
\hline Sonchus asper & Th & An & - & - & - & - & - & - & - & - & - & + & + & - & - & - & - & - & + & - & - & - \\
\hline Sorbus aria & $\mathrm{Ph}$ & Zo & - & + & - & - & - & - & - & - & - & - & - & - & - & + & + & - & - & - & - & - \\
\hline Taraxacum officinale & $\mathrm{H}$ & An & - & - & - & - & - & - & - & - & - & - & + & + & + & - & + & - & - & - & - & - \\
\hline Teucrium scorodonia & G & $\mathrm{Ba}$ & - & - & + & - & - & - & - & - & - & - & + & + & + & + & + & + & + & + & + & + \\
\hline Trifolium pratense & $\mathrm{H}$ & An & - & - & - & - & - & - & - & - & - & - & + & - & - & - & - & - & - & - & - & - \\
\hline Trifolium repens & $\mathrm{H}$ & An & - & - & - & - & - & - & - & - & - & - & + & - & - & - & - & - & - & - & - & - \\
\hline Trisetum flavescens & $\mathrm{H}$ & An & - & - & - & - & - & - & - & - & - & - & - & + & + & - & - & - & - & - & - & - \\
\hline Tussilago farfara & G & An & - & - & - & - & - & - & - & - & - & - & + & + & + & - & + & + & + & - & - & - \\
\hline Urtica dioica & $\mathrm{H}$ & An & - & - & - & - & - & - & - & - & - & - & + & + & + & + & - & + & - & - & - & - \\
\hline Verbascum pulverulentum & $\mathrm{H}$ & Zo & - & - & - & - & - & - & - & - & - & - & + & + & - & - & - & - & - & - & - & - \\
\hline Veronica officinalis & $\mathrm{H}$ & Hy & - & - & - & - & - & - & - & - & - & - & + & + & + & + & + & + & + & + & - & - \\
\hline Vicia articulata & $\mathrm{H}$ & $\mathrm{Ba}$ & - & - & - & - & - & - & - & - & - & - & - & + & - & - & - & - & - & - & - & - \\
\hline Vicia hirsuta & $\mathrm{H}$ & $\mathrm{Ba}$ & - & - & - & - & - & - & - & - & - & - & + & + & - & - & - & - & - & - & - & - \\
\hline Vicia sativa & $\mathrm{H}$ & $\mathrm{Au}$ & - & - & - & - & - & - & - & - & - & - & + & + & + & - & - & - & - & - & - & - \\
\hline Viola odorata & $\mathrm{H}$ & $\mathrm{Zo}$ & - & - & - & - & - & - & - & - & - & - & - & - & + & - & + & - & - & - & - & - \\
\hline
\end{tabular}

LF: life form, Ch: chamaephytes, G: geophytes, H: hemicryptophytes, Ph: phanerophytes, Th: therophytes. DM: dispersal mode, An: anemochorous, $\mathrm{Au}$ : autochorous, Ba: barochorous, Hy: hydrochorous, Zo: zoochorous. 